\title{
COMUNICAREA CREDINŢEI PRIN COMUNIUNE. PĂRINTELE PROFESOR DUMITRU STĂNILOAE - ILUSTRU TEOLOG AL COMUNIUNII
}

\author{
Mihai HIMCINSCHI* \\ Marius GOLEA*
}

\begin{abstract}
Communication of faith through communion. Father Professor Dumitru Stăniloae - illustrious theologian of communion. The purpose of the present article is that of highlighting the communication of the faith through communion, this being a central focusing point in the writings of Priest Dumitru Stăniloae. In order to achieve this, we have analyzed a vast part of His Holiness's writings, a iming to offer an overall view on the recurrence of the concept of faith's communication through communion, in his theological work. Thus we have ascertained the omnipresence of this relentless urge of coming back to Christ, of believer's self-situating in the frame of the Church, in the communion of love, and in the together-working with Christ and with the Holy Spirit. Father Stăniloae insists, time and again, upon the fact that we cannot be saved in isolation, but only within the communion and within the community of the Church, having as ideal the supreme model of communion of love of the Most Holy Trinity. The purpose of the man's earthly life is to work the commandments within the Church's community and communion, so that to set himself free from the sin's and egotism's prison, and to become transparent to Christ and to the Holy Spirit, and thus, through the work of the savior grace and through godlike condescendence, to be foun d worthy of adoption and deification, respectively to be saved. The general conclusion we have drawn consequently to this study, is that the notion of communion is fundamental to the theological work of Priest Dumitru
\end{abstract}

* PhD, Rev., Professor, Dean, Faculty of Orthodox Teology at „1 Decembrie 1918” University, Alba Iulia, Romania.

*PhD Student, Faculty of Letters, History and Theology, at „West University”, Timişoara, Romania. 
Stăniloae, and the communication of the faith within the Church's communion is the only possible way.

Keywords: Church, Communication, Communion, Most Holy Trinity, Priest Professor Dumitru Stăniloae, Revelation, right-faith.

\section{1. „Credința, ca lucrare a Duhului, vine în cineva prin altul" 1}

Părintele profesor Dumitru Stăniloae poate fi considerat drept cel mai mare teolog al comuniunii pe care 1-a cunoscut teologia creștină, în general, şi teologia ortodoxă, în special. El a dezvoltat termenul de comuniune până la nuanțe cu totul inedite, dar 1-a şi așezat în rândul noțiunilor soteriologice fundamentale, fără de care persoana umană nu îsisi poate îndeplini menirea, respectiv nu se poate mântui.

Credința, în doctrina părintelui Stăniloae, este rezultatul comunicării dintre persoanele umane, ori dintre persoana umană și Persoana Divină. În textele veterotestamentare vedem cum credința este generată, dar și facilitată, de comunicarea dintre Dumnezeu și profeți. În Noul Testament, Fiul lui Dumnezeu cel Întrupat, vine în Persoană și le comunică apostolilor, dar și celor care, ocazional, ori pentru perioade mai lungi ori mai scurte, stau în preajma Lui, Revelaţia. Vindecările pe care Fiul Omului le face sunt „fundamentate” pe credinţa celor care sunt vindecaţi, dar, totodată, într-o măsură mai mare ori mai mică, prin intermediul acelor vindecări le este comunicată celor vindecați credința; această comunicare a credinței îi vizează și pe cei care sunt martori la vindecări.

Citirea cuvântului Sfintei Evanghelii adusă de Hristos este, de asemenea, un act de comunicare a credinței. Sfânta Scriptură este în fapt o comunicare mereu nouă, înnoită, actuală, dar și constant situată în adevărul de credință inițial. Scriptura este o comunicare scrisă a Cuvântului lui Dumnezeu, o comunicare ce nu poate fi schimbată în conținutul ei, dar care, odată cu evoluţia istorică, este explicată mereu mai profund și mereu mai actual, astfel încât Adevărul să poată fi înțeles de cei cărora li se adresează, respectiv de publicul țintă, de receptorii comunicării.

${ }^{1}$ Dumitru Stăniloae, Teologia Dogmatică Ortodoxă, vol. I, Bucureşti, EIBMBOR, 1996, p. 41. 
Credința este deci rezultat al comunicării dintre persoane, comunicare care este cu atât mai eficientă cu cât emitentul/generatorul comunicării este mai credincios, caz în care el are „,cuvânt cu putere multă" (Lc. 4, 32; Fapte 19,20). Iată ce spune părintele Stăniloae în acest sens:

„(...) în general, cuvântul Scripturii are putere când e comunicat de un om credincios altuia, fie prin repetarea lui așa cum se găsește în Scriptură, fie explicat. Căci în credința dintre ei lucrează Duhul Sfânt (care-L face prezent și lucră tor pe Hristos, n.n.). Credința, ca lucrare a Duhului vine în cineva prin altul, darnumai când acel altul comunică cuvântul Scripturii însuşit şi mărturisit cu credință, sau cu sensibilita tea comuniunii în Duhul. Scriptura își activează puterea ei în comuniunea dintre persoane, în transmiterea cuvântului ei cu credință de la o persoană la alta, de-a lungul generațiilor"2.

Îndrăznim să afirmăm că, în legătură cu transmiterea credinței de la o persoană la alta, părintele Stăniloae instituie, în mod simbolic, un fel de taină a hirotoniei, dar în cazul comunicării credinței prin comuniune, această taină este oficiată de cel credincios asupra celui care urmează a primi credința, nu prin punerea mâinilor, ci prin punerea sufletului ${ }^{3}$.

Dacă ne referim la citirea Sfintei Scripturi, prin vocea celui care rostește cuvintele Scripturii ni se adresează Insuși Mântuitorul Hristos, îndemnându-ne ca, în comuniunea Bisericii, să venim la credință, să-L primim pe Cel Care „stă la ușa inimii noastre și bate” (Apoc. 3, 20), astfel ca noi să-L putem auzi și primi în casa sufletului nostru, unde El să-Şi facă locaș, unde noi să ajungem să fim preoți care să slujească sfânta jertfă a dragostei pe altarul sufletului nostru, curățit și pregătit prin lucrarea harului. Ca rezultat al comunicării adevărului de credință în comuniune, nu primim doar o cunoaștere intelectuală, ci primim în noi lucrarea harului mântuitor. Părintele Stăniloae prezintă procesul de comunicare a credinței ca un proces continuu, într-o continuă evoluție, astfel că credința:

„(...) se dă nu numaide înțelesurile ei duhovnicești, ci şi de lucrarea Duhului lui Hristos săvârșită prin aceste înțelesuri în cel ce citește, sau de

\section{${ }^{2}$ Ibidem.}

${ }^{3}$ Marius Golea, Biserica - laborator al mântuirii, în opera Părintelui Profesor Dumitru Stăniloae. Mic tratat de soteriologie practică, Arad, 2019, p. 61. 
Hristos Însuși, Care-Și descoperă tot mai adânca bogăție spirituală a Lui"'4.

Preluând de la Sfântul Maxim Mărturisitorul doctrina întregii creații ca Biserică, părintele Dumitru Stăniloae o dezvoltă într-o kerigmă de mare forță duhovnicească, afirmând că Biserica are trei „,niveluri”: cea a persoanei umane, cea a familiei și cea a întregii creații ${ }^{5}$. Prin lucrarea faptelor credinței, de la nivelul persoanei, se comunică credința în interiorul bisericii mici a familiei ${ }^{6}$, iar comunitatea tuturor familiilor de credincioși creștini este chemată, prin participarea la comunitatea mai mare a Bisericii luptătoare, să îndumnezeiască întreaga creație și să o aducă lui Dumnezeu drept jertfă bine-primită.

Iată ce expresive sunt considerațiile părintelui Stăniloae la adresa familiei ca mediu de comunicare a credinței în comuniune:

„Faptul că putem vedea pe Dumnezeu prin altul, că iubirea față de altul ni-L face pe acela transparent allui Dumnezeu, e un daral întrupării Cuvântului" "; , ,(..) omuln-ar fi chipul lui Dumnezeu dacă ar fio monadă închisă”; „Omul este o unitate completă, deci chip al lui Dumnezeu, pentru că unitatea sa de om se realizează în dualitatea personală neuniformă, ci complementară, de bărbat și femeie (...)” și că: „Omul e bipolar în sine însuși. Numai așa e ființă dialogică" ${ }^{\prime}$.

\section{Comunicarea credinței prin comuniune, ca răspundere față de aproapele}

Actul iniţiatic al comunicării credinței în comuniunea cu aproapele implică totodată o mare responsabilitate. Această răspundere primește caracteristicile comuniunii, în principal aceea a caracterului biunivoc al comunicării credinței. Cel care comunică are, față de destinatarul comunicării sale, responsabilitatea unei lucrări cât mai eficiente, dar și destinatarul comunicării are datoria de a se deschide comunicării, astfel încât să poată primi conţinutul ei.

${ }^{4}$ Dumitru Stăniloae, Teologia Dogmatică Ortodoxă, vol. I, p. 42.

5 Idem, Spiritualitate și comuniune în Liturghia Ortodoxă, Ed. a II-a, Bucureşti, EIBMBOR, 2004, p. 43.

${ }^{6}$ Ibidem.

${ }^{7}$ IDEM, Teologia Dogmatică Ortodoxă, vol. III, Bucureşti, EIBMBOR, 1997, p. 120.

${ }^{8}$ Ibidem, p. 121. 
Credincioșii sunt responsabili pentru credința celuilalt, atât în fața lui Dumnezeu, cât şi în fața aproapelui. Comunicarea credinței în comuniune are loc şi ca urmare a apelului venit din partea aproapelui, prin care el ne cere să ne rugăm pentru el. Acest apel, în viziunea părintelui Stăniloae, trezește în noi impulsul de a ne ruga pentru cel care a făcut solicitarea, căci ne vedem responsabili pentru el:

„Apelul pe care-1 face un credincios către altul: "Roagă-te pentru mine, frate (sau părinte)!” e manifestarea conștiinței lui că depinde simultan de Dumnezeu și de aproapele. Dar e și un apel la răspunderea aceluia în fața lui Dumnezeu, însă la o răspundere în care se include răspunderea pentru semenii lui și în speță pentru cel care face apel prin el. Prin acest apel trezește răspunderea îndoită a aceluia: faţă de Dumnezeu și față de cel care face apelul. În a cest sens, chiar cel care face apelul că tre cineva îi dă prilejul aceluia să se trezească. Dialogul constă din apelul unuia și din răspunsul oarecum necesaral celuila lt. Apelului trebuie să -i urmeze răspunsul"'.

În ceea ce privește caracterul ambivalent al comunicării credinței în comuniunea credincioșilor și a acestora cu Dumnezeu, părintele Stăniloae, printr-un trop de tip chiasm, extinde analiza comunicării prin evidențierea plastică a caracterului necesar al comuniunii cu Dumnezeu şi a necesităţii comuniunii cu aproapele, și viceversa:

„(...) amândoi se simt răspunzători simultani în fața lui Dumnezeu unul pentru altul. Amândoi sunt legați de Dumnezeu şi unul de altul prin răspunsul pe care trebuie să-l dea fiecare lui Dumnezeu pentru celălalt. Apelul reciproc la rugăciune trezește legătura lor dialogică cu Dumnezeu și întreolaltă, ca fünțe răspunzătoare față de Dumnezeu și întreolaltă. Legătura între credincioși este o legătură în Dumnezeu și invers: legă tura unui credincios cu Dumnezeu este o legătură cu ceilalți” ${ }^{10}$.

În familie, ca biserică mică, în întrajutorarea reciprocă pe calea îngustă a mântuirii, pot fi regăsite, simbolic, Sfintele Taine, de la mărturisirea greșelilor la iertarea celui care ne-a greșit, de la rugăciunea pentru altul la împărtășirea dragostei părintești. S-ar putea spune că

\footnotetext{
${ }^{9}$ IDEM, ,Rugăciunile pentru alții și sobornicitatea Bisericii”, în Studii Teologice, an. XXI, nr. 1-2/1970, p. 31.

${ }^{10}$ Ibidem.
} 
familia creștină este mediul în care se săvârșește o liturghie continuă, o lucrare continuă în care, în comuniune, este comunicată și întărită credința membrilor ei. Părintele Stăniloae insistă de asemenea pe importanța și eficiența exemplului personal în această împreună-lucrare a familiei:

„Membri familiei sunt chemați să-și dea în acest scop în primul rând lor un ajutor reciproc. Ei sunt chemați să -și ierte greșelile ce le să vârșesc ca oameni, să se îndemne cu cuvântulși cu pilda la ferirea de lucruri urâte, să se ajute în cele bune, să se îngrijea scă unul de altul și să se îndemne cu pilda la rugăciune"11.

\section{Biserica este mediul în care, prin comuniunea dintre credincioși cu Sfânta Treime și dintre credincioși între ei, se comunică credința creștină}

Comunicarea credinței are loc în mediul de adâncă comuniune reprezentat de Biserică. Este necesar să se sublinieze iar și iar faptul că Biserica trebuie văzută drept comuniune a credincioșilor, dar și drept comuniune a Bisericii luptătoare cu Biserica triumfătoare și cu Dumnezeu. Nu trebuie nici un moment uitat faptul că Hristos este prezent în comuniunea Bisericii, că este Cap al Bisericii, că Sfântul Duh este prezent în Biserică și în Sfintele Taine, că niciun moment nu suntem singuri, iar credința ne este comunicată, până la urmă, în măsura în care, prin lucrarea poruncilor, suntem găsiți vrednici de cea mai înaltă comuniune posibilă, anume aceea de a deveni transparenți Duhului Sfânt și locaș Fiului lui Dumnezeu.

Așa cum am arătat și cu altă ocazie ${ }^{12}$, Sfânta Scriptură este citită și interpretată în Biserică, interpretarea einefiindîn nici un cazo schimbare, o adăugare, ci o explicare a ei în contextul socio-cultural în care citirea și interpretarea au loc - în comunicarea misionară trebuie ținut cont de evoluția parcursă de sociolect și de idiolect la momentul efectuării comunicării. Prin această activitate, Revelația este de asemenea menținută în eficiență în Biserică, respectiv, prin interpretare se creează

${ }^{11}$ Idem, Spiritualitate și comuniune în Liturghia Ortodoxă, p. 44.

${ }^{12}$ Mihai HimcinsCHI, „Misiune și limbaj biblic”, în Annales Universitatis Apulensis. Series Teologica $\mathrm{nr} .5 / 2005$, p. 75. 
posibilitatea ca o anumită generație, la un anumit moment istoric, să poată înțelege mesajul Evangheliei lui Hristos.

Desigur că orice comunicare interpretativă ascunde riscurile îndepărtării de conținutul original al comunicării, însă Biserica veghează ca presupunerile, făcute de cei care interpretează textului biblic, să nu devieze de la fundamentul doctrinar al dreptei credințe:

„Teologii ortodocși vor insista pe faptul că de vreme ce nu există lucruri de genul tă lmăcire fără presupuneri, exegeza critică ar trebuie să ducă la baza presupunerilor bisericești. Citirea Bibliei nu este acelaşi lucru cu citirea oricărei alte cărți, ea presupune iluminarea inimilor noastre (II Cor. 4, 6) prin Duhul Sfânt în Biserică"13.

Comuniunea Bisericii are ca model comuniunea perihoretică a Persoanelor Sfintei Treimi, iar comunicarea credinței în comunitatea Bisericii trebuie să tindă, atât cât este posibil oamenilor, către comunicarea care are loc în comunitatea supremă de iubire dintre Tatăl și Fiul, întru Duhul Sfânt și de la Fiul, către Tatăl, prin Duhul.

In esența sa, Biserica poate fi considerată drept un organ de comunicare a Revelației, Revelație care rămâne în eficiență $\breve{l}^{14}$ în mediul Bisericii, deoarece Hristos și Duhul Sfânt - și deci întreaga Sfântă Treime - sunt prezenți în Biserică, în slujirea Sfintei Liturghii și a SfintelorTaine.

Caracterul mântuitor al apartenenței la comunitatea Bisericii este dat deci, de faptul că, fiind în comuniune cu Biserica, suntem în comuniune cu Însuşi Hristos; în comuniunea Bisericii ni se comunică dreapta credință, iar noi avem datoria să luăm asupra noastră, atât cât este posibil omului, starea de jertfă continuă în care Domnul nostru Iisus Hristos Se află, de-a dreapta Tatălui, după Înviere și Înălțarea cu trupul la ceruri. Astfel:

„(...) sta rea de mântuire echiva lea ză cu a partenența la Biserică, sau cu concentrarea celor mântuiți în Biserică, cu participarea lor comună la trupul lui Hristos, ridicat mai presus de orice preocupare de Sine prin starea de jertfă permanentizată în El. În baza Ipostasului Său divin şi a stării Sale de jertfă, Hristos vrea și poate să-i adune pe toți, extinzându-

${ }^{13}$ Ibidem, p. 76.

${ }^{14}$ Dumitru Stăniloae, Teologia Dogmatică Ortodoxă, vol. I, p. 38. 
Se în ei prin Duhul Sfânt, Care le imprimă aceeași dispoziție de jertfă din trupul lui Hristos" 15 .

Credința se comunică în comuniune, deoarece comuniunea este cea care ne of eră mijloacele necesare pentru a ieși din izolarea individualistă și egoistă, astfel încât să ne eliberăm din închisoarea în care ne-a izolat păcatul. Comunicarea credinței trebuie să se facă de către persoana sursă a comunicării, în stare de jertfă, având drept țintă atingerea, de către destinatarul comunicării, a aceleiaşi stări de jertfă, deoarece, așa cum arată părintele Stăniloae:

„(...) numai prin jertfă, predându-ne lui Dumnezeu, dă râmăm zidurile care ne închid în mărginirea noastră și intrăm în comuniune deplină cu Dumnezeu și cu semenii”" ${ }^{6}$.

Hristos este prezent în Biserica Sa și, dacă venim în comuniune cu El, prin participarea la Sfânta Liturghie, prin primirea Sfintelor Taine, El Se comunică tot mai mult nouă, pe măsura în care noi lucrăm poruncile Sale, iar, pe măsura în care efortul nostru spre mântuire este tot mai mare, Hristos ne ridică spre El și Se pogoară spre noi, împreună cu Duhul Sfânt, ca să ne facă tot mai capabili de a primi Adevărul dreptei credințe. Dar Hristos, arată părintele Stăniloae, se află în credincioșii uniți în Biserica Sa, iar nu în cei care aleg căi separate, care despart, care scot din comuniune:

„El nu Se află în credincioșii izolați sau despărțiți prin păreri deosebite despre El. Căci a venit (...) să ne unim în El, adică în aceeașicredință în El, care nu e decât Unul și Același; sau în El ca Adevărul, sau ca Fiul lui Dumnezeu făcut om, putând cuprinde ca stare pe toțiși pe toa te. Căci Fiul lui Dumnezeu S-a făcut om ca să adune în Dumnezeu toată creația Lui, nu s-o dezbine. Biserica este, de aceea, unirea celor ce cred în Hristos Cel Unul și adevărat"17.

Hristos Iisus rămâne forța centrală a Bisericii Sale, centrul de atracție către unirea credincioșilor în comuniunea Bisericii - singura care poate comunica dreapta credință - ca un foc de iubire, care luminează

15 Ibidem, p. 96.

${ }^{16}$ Ibidem, p. 98.

${ }^{17}$ IDEM, Iisus Hristos lumina lumii şi îndumnezeitorul omului, Bucureşti, Edit. Anastasia, 1993, p. 213. 
mereu calea celor care-L caută. Hristos ne îmbie cu ceea ce nici o altă religie nu oferă: să intrăm într-o aşa de mare comuniune cu Persoanele Sfintei Treimi, prin Fiul, prin lucrarea Sfântului Duh, încât să devenim frați ai Fiului, deci fii ai Tatălui, iar prin aceasta dumnezei (Mt. 5, 45; In. 10, 34-35). Iată cum prezintă părintele Stăniloae, foarte sugestiv, această înfiere și îndumnezeire:

"Hristos este misterul culminant centralîn continuă ira diere de putere și de a tracție la unirea cu Sine a oamenilor, făcând din această unire, al cărei focar este, misterul lărgit al Bisericii. El este izvorul continuu curgător de putere în Biserică, întreținând neîncetat viața dumnezeiască în ea. Prin aceasta ceice primesc din puterea Lui devin tot mai intim uniţi nu numaicu El, ci și întreola ltă. Viața curgă toare din Hristos fiind o viață a iubirii, pătrunde în ei ca o altă Persoană dumnezeiască, adică Duhul Sfânt. Duhul Sfânt îi încă lzește pe oameni de dragostea față de Hristos, îi face să simtă dragostea Lui de Frate central al lor și le insuflă dragostea Lui filială față de Tatăl. Simțindu-se toți frați ai aceluiași Hristos și fii ai a celuia și Părinte ai Lui, se simt și între ei frați. Ei intră prin aceasta într-o viață de comuniune tot mai deplină, însuflețită tot mai mult de Hristos, articulându-se spiritual ca mădulare ale trupului Lui" ${ }^{18}$.

Comuniunea cu Fiul ne aduce în oceanul de iubire al Sfintei Treimi, căci, prin primirea și lucrarea harului, devenim capabili a ne bucura de această iubire:

„În comuniune cu El (cu Hristos, n.n.) fiecare om, devenit fiul Ta tă lui prin har, se bucură de dragostea deplină a Ta tălui lui Hristos, iar TatălSe poate bucura de dragostea perfectă a omului Hristos, devenit Fiul Lui, dragoste în care se unește dra gostea tuturor celor ce cred în El" 19 .

Dar Hristos face posibilă comuniunea persoanei umane cu Persoanele Sfintei Treimi întrucât e și El Însuși Om adevărat - și Dumnezeu adevărat -, iar prin Înălțarea cu trupul la ceruri a dus și a așezat, de-a dreapta Tatălui și în comuniunea de iubire a Prea Sfintei Treimi, omul:

„Hristos e Persoana divină care Ea însăși, füind și om, face posibilă, prin comuniune accesibilă cu ea ca om, comuniunea tuturor cu Dumnezeu

${ }^{18}$ IDEM, „Biserica și viața - Realitatea tainică a Bisericii”, în Ortodoxia, an. XXXIV, nr. 3/1984, p. 417.

${ }^{19}$ IDEM, Teologia Dogmatică Ortodoxă, vol. I, p. 59. 
Însuşi, sau cu Persoana absolută. El este centrul și fundamentul acțiunii de extindere a mântuirii și de îndumnezeire la toți cei ce cred. În El planul de mântuire s-a realizat ca într-un fundament"20.

Comuniunea supremă de iubire dintre Persoanele Preasfintei Treimi are drept consecință faptul că, în Biserică, Hristos și Duhul Sfânt Se află și lucrează în comuniune, însă păstrând caracterul personal al lucrărilor și fără a fi nici un moment vorba de vreo confundare ori amestecare. Dar această împreună lucrare are ca fundament comuniunea, pe baza căreia se întemeiază toată lucrarea mântuitoare de aducere la credință și de comunicare a dreptei credințe către credincioși, în Biserică:

„Duhul lui Hristos ne sensibilizează pentru Hristos și ne unește cu El în Biserică, pentru că focul Duhului care se propagă din Hristos nu se poate despărți de sensibilitatea umană comună pentru Hristos. El se manifestă ca lucrător prin focul credinței lucrătoare. Focul acesta este viața în continuă desă vârșire a comuniunii cu Hristos. Duhul a duce viața pentru că realizează comuniunea cu Hristos"21.

Mai mult, prezența Fiului ne indică prezența Tatălui și a Duhului în întreaga lucrare de îndumnezeire a creației:

„Hristos ara tă prin Sine pe Tatăl și pe Duhul, săvârșind împreună cu Ei opera de ridicare a omenirii la comuniunea eternă cu Sfânta Treime, care este Ea Însăși structura comuniunii perfecte" ${ }^{22}$.

Comunicarea credinței nu ar fi posibilă fără conlucrarea Sfântului Duh. Părintele Stăniloae arată că punerea credincioșilor în comuniune cu Hristos, în Biserică, nu are loc în izolare, ci în unitatea lor. Credinciosul nu poate fi în comuniune cu Hristos dacă nu este în comuniune cu aproapele:

„Prin Duhul credincioşii nu sunt legați în izolare de Hristos, ci împreună. Cel ce ajunge la credința în Hristos ajunge prin credința sau sensibilitatea altuia. Sensibilitatea interpersonală a credinței în care Se manifestă Duhul Sfânt îi leagă pe cei ce cred în comunitatea credințeiîn Biserică. Sensibilita tea bucuriei pentru comunitatea cu Persoana absolută

\footnotetext{
${ }^{20}$ Ibidem, p. 37.

${ }^{21}$ Ibidem, p. 39.

${ }^{22}$ Ibidem, p. 56.
} 
a lui Hristos se extinde în bucuria comuniunii și a faptelor de comuniune cu alții, în participarea altora la Persoana absolută a lui Dumnezeu, venită la nivelul comuniunii cu ei în Hristos"23.

\section{Concluzii}

Comunicarea credinței nu poate avea loc decât în comuniune. Acolo unde comuniunea lipsește, credincioșii nu mai pot fi mlădițe ale viței celei bune a dreptei credințe, ci, dimpotrivă, ei cad din adevăr în cele contrare. În legătură cu aceasta, părintele Stăniloae arată că:

„Unde lipsește comuniunea domnește minciuna, para vanul sub care se ascunde mereu un ins de altul. Integra rea inșilor într-o unitate rea lă, întro comunitate închegată, se dovedește prin faptul că spun adevărul în iubire, spre zidire reciprocă ${ }^{24}$.

Credința ne este comunicată prin intermediul unei alte persoane, în colaborare cu Sfântul Duh. Persoana care ne comunică credința trebuie să fie în comuniune cu noi, o comuniune care înseamnă totodată o mare responsabilitate față de mântuirea destinatarului comunicării. Responsabilitate are însă și cel care este beneficiarul comunicării, căci el trebuie să-și deschidă sufletul pentru a putea primi conţinutul comunicării, iar el poate face aceasta numai dacă se plasează voluntar în comuniune cu cel care inițiază comunicarea credinței.

Biserica lui Hristos este mediul în care credința este comunicată în comuniunea cu aproapele, dar și cu Persoanele Sfintei Treimi. Întreaga lucrare a Bisericii are ca scop îndumnezeirea omului și a creației și aducerea lor, ca jertfe bine primite, Creatorului. Biserica are ca model comuniunea supremă de iubire dintre Persoanele Sfintei Treimi și cheamă credincioșii să devină altare ale Sfântului Duh, fii ai Celui Preaînalt, frați ai Fiului după har.

Comunicarea credinței în comuniunea Bisericii nu este o activitate teoretică, ci mai degrabă un proces ontologic, dinamic și eficient, care are loc sub conducerea lui Hristos, Capului Bisericii. Prezența și lucrarea lui Hristos și a Sfântului Duh în Biserică fac posibilă comunicarea credinței în comuniune și mântuirea credincioșilor prin înfiere și îndumnezeire.

23 Ibidem, p. 39.

${ }^{24}$ IDEM, „Comunitate prin iubire”, în Ortodoxia, an. XXI, nr. 1/1963, p. 56. 


\section{Referinţe bibliografice:}

1. GoleA, Marius, Biserica - laborator al mântuirii, în opera Părintelui Profesor Dumitru Stăniloae. Mic tratat de soteriologie practică, Arad, 2019;

2. HIMCINSCHI, Mihai, „Misiune și limbaj biblic”, în Annales Universitatis Apulensis. Series Teologica, nr. 5/2005, p. 73-86;

3. STĂNILOAE, Dumitru, „Biserica şi viaţa . Realita tea tainică a Bisericii”, în Ortodoxia, an. XXXIV, nr. 3/1984, p. 415-420;

4. STĂNILOAE, Dumitru, „Comunitate prin iubire”, în Ortodoxia, an. XXI, nr. 1/1963, p. 52-70;

5. StĂniloAe, Dumitru, Iisus Hristos, lumina lumii şi îndumnezeitorul omului, Bucureşti, Edit. Anastasia, 1993;

6. STĂNILOAE, Dumitru, „Rugăciunile pentru alții și sobornicitatea Bisericii”, în Studii Teologice, an.XXI, nr. 1-2/1970, p. 1-38;

7. STĂNILOAE, Dumitru, Spiritualitate şi comuniune în Liturghia ortodoxă, Ed. a II-a, Bucureşti, EIBMBOR, 2004;

8. STĂNiloAe, Dumitru, Teologia Dogmatică Ortodoxă, vol. I, Bucureşti, EIBMBOR, 1996;

9. StĂNiloAe, Dumitru, Teologia Dogmatică Ortodoxă, vol. III, Bucureşti, EIBMBOR, 1997. 